\title{
PREVALENCE, ETIOLOGY AND ANTIBIOGRAM OF MASTITIS IN BUFFALOES IN SOHAG GOVERNORATE
}

\author{
NEHAL MAKRAM AWAD \\ Dept. of Bacteriology, Animal Health Research Institute, Sohag Laboratory
}

Received: 30 September 2019; Accepted: 29 October 2019

\begin{abstract}
In this study total of 416 milk samples (104 buffaloes) which were reared in a smallholder private cases hand milked in Sohag Governorate were examined. Clinical screening of examined animals beside the results of California mastitis test for apparentely healthy animals revealed that the overall prevalence rate of clinical and subclinical mastitis were $22.1 \%$ and $26.9 \%$, respectively. The incidence of one quarter infection was the highest followed by all quarters in clinical and subclinical mastitis cases at the percentage of $30.4 \%, 35.7 \%, 26.2 \%$ and $28.6 \%$ respectively. The third lactating season was the highest incidence of both clinical and subclinical mastitis at the percentage of $28.6 \%$ and $35.3 \%$ respectively. By bacteriological examination 56 isolates from clinical mastitic cases and 68 isolates from subclinical mastitic animals were detected. Staphylococcus aureus , E.coli and , Streptococcus agalactia were isolated by ratio $16.1 \%, 33.9 \%, 14.3 \%$ and $29.4 \%, 22.1 \%, 10.3$ in cases of clinical mastitis and subclincal ones respectively. staphylococcus aureus and E. coli staphylococcus aureus and streptococcus agalactia and staphylococcus aureus and E-coli microorganisms were mixed isolated by ratio $7.1 \%, 7.1 \%$ and $5.4 \%$ in cases of clinical mastitis and $8.8 \%, 4.4 \%, 4.4 \%$ in subclinical mastitic cases. Mixing of more than 3 isolates or more was the rate of clinical mastitis $8.9 \%$, whereas subclinical mastitic were $8.8 \%$. Simplex and multiplex PCR assays showed that E-coli isolates were the highest causative agents of clinical mastitis and staphylococcus aureus was the major cause of subclinical mastitic ones. Antimicrobial susceptibility testing revealed that all isolates were highly sensitive to Gentamycin Ceprofloxacin, Lincomycin and Novobiocin followed by Chloramphenicol, Cephalothin and Amoxycillin.
\end{abstract}

Key words: Buffalo, lactation, clinical \& subclinical mastitis, prevalence.

\section{INTRODUCTION}

Mastitis is still the most important and widespread zoonotic production disease in milking herds in all species of farm animals, despite several decades of research and remedial efforts. It has a long range of damaging effects on productive performance of animals (Seegers et al., 2003).

In Egypt buffalo appears to be the first animal for milk yield rather than meat production and approx. $65 \%$ (or may be more) of the daily milk production in Egypt is obtained from dairy buffaloes (Metry, 1996). The majority of Egyptian buffaloes' population is apparently still under the farmer's hand (private cases) rather than that those kept on farms for milk and meat production. However, the majority of literature on mastitis of dairy animals at Upper Egypt is focused on Friesian cows and on buffaloes that located on farms (Seddek et al., 1999).

Corresponding author: Nehal Makram Awad E-mail address: nehalmakram63@ gmail.com Present address: Dept. of Bacteriology, Animal Health Research Institute, Sohag Laboratory
Clinical and subclinical mastitis recorded in buffalo and it considered one of the most economically important deadly diseases of milky animals, and causes the changes in glandular tissues affecting quality and quantity of the milk (Sharma and Sindhu, 2007). Mastitis is characterized by physical, chemical, bacteriological, cytological changes in milk and pathological changes in the gland. Clinical mastitis recognized by abnormal milk, gland swelling and /or systemic illness whereas subclinical mastitis characterized by apparently normal milk with an increase in SCC due to influx of leukocyte with reduces in milk production. (Philip et al., 1993).

Mastitis is defined as an inflammatory reaction of the parenchyma of the mammary gland that can be of an infectious, traumatic or toxic nature (International Dairy Federation 1987). Mastitis may result in the presence of bacteria and other infectious agents which may be harmful to humans, (Reyher and Dohoo, 2011). The prevalence of intramammary infection in buffalo was $66 \%$. Since the mammary gland is highly susceptible to infection during the periparturient period, the incidence was highest during the 30 days 
after calving. Since mastitis is a diseases caused by multiple factors (multiple pathogens), it is difficult to control (Andrei et al., 2011).

Over one hundred different microorganisms have been isolated from bovine mastitis, but the most frequently isolated microorganisms are Staphylococci, Streptococci and Gram-negative bacteria (Hussain et al., 2012; Hussain et al., 2013). Mastitis-causing bacteria can be classified in contagious as Streptococcus agalactiae, Stapylococcus aureus, Arcanobacter piogenes, Micoplasma; environmental as Streptococcus uberis, and dysgalactiae, Escherichia coli, Enterobacteriacee, yeasts and moulds (Protothecazoophii) and opportunist as coagulase negative Staphilococcus C.N.S (Galiero, 2002). In buffalo Incidence of subclinical mastitis more prevalent than clinical mastitis in housed buffaloes in percentages $18.5 \%$ and $9 \%$ respectively. S. aureus, E. coli, St agalactia and St. dysgalactia were the most common isolates in clinical mastitis. E. coli, S. aureus, C.N.S, Pseudomonas, St agalactia, and St. dysgalactia were the most common isolates in subclinical mastitis. Mixed infection by S. aureus and E. coli common cause in clinical mastitis $24.4 \%$ and $S$. aureus and C.N.S common cause in subclinical mastitis 18.9\% (Abd-Elrahman, 2013).

Due to the limitations of cultural methods, the development of PCR-based methods provides a promising option for the rapid identification of bacteria. With these methods, identification of bacterial pathogens can be made in hours, rather than the days required for conventional cultural methods Yu-Ping et al. (2007). PCR can also improve the level of detection due to its high sensitivity. Theoretically, only a few cells of the pathogen are necessary to yield a positive diagnosis The presence of pathogens may be detected at earlier stages of infection and in carrier animals, when the numbers of bacteria in milk may be very low (Pradhan et al., 2011).

The present study was designed to see the prevalence of mastitis (clinical and subclinical) in buffaloes in relation to lactation season, quarters affected, injury on the teat, involvement of different organisms and their antimicrobial sensitivity. Also it is aimed to use PCR assays for the detection of Staphylococcus aureus, Escherichia coli and Streptococcus agalactiae in mastitic milk samples.

\section{MATERIALS AND METHODS}

\section{Animals}

\section{Sample collection:}

416 quarter milk samples (104 buffaloes) were collected from small holder dairy farms at age of 3-6 years and 1-4 lactating seasons from September till
December 2018 at Sohag Governorate. Signs and symptoms were recorded to clinical mastitic cases (Schalm et al., 1976). Quarter milk samples from udder were categorized as subclinical mastitis based on the following criteria: absences of visible abnormalities of milk secretions, California mastitis test (CMT) (Gonzalez et al., 1990).

\section{California Mastitis Test (CMT):}

The CMT was used alongside the physical examinations and the test was carried out as described. Equal volume of milk samples which were taken during milking time and the CMT reagent $(2 \mathrm{ml}$ of each quarter) and was mixed thoroughly in a cup of black plastic paddle; the mixture was gently rotated for 10 seconds, and then results were recorded (Moroni et al., 2006).

\section{Estimation of Somatic Cell Count (SCC):}

Milk samples were thoroughly mixed and from each sample $0.01 \mathrm{ml}$ was spread over an area measures 1 $\mathrm{cm}^{2}$ of a glass slide then left to air dried and stained by Newman-Lampert stain and examined microscopically according to (Alekish et al., 2014).

\section{Milk sampling}

The infected teat end was disinfected with cotton soaked in $70 \%$ ethyl alcohol. The first few streams of foremilk were discarded. Samples for bacteriological analysis were then collected into screw capped sterile McCartney bottle and were held on ice until delivery to the laboratory within 20 to $30 \mathrm{~min}$ of collection the samples were preserved at $-20 \mathrm{C}^{\circ}$ till send to Animal Health Research Institute for Bacterial isolation and identification. (Soomro et al., 2002).

\section{Bacteriological examinations:}

Bacteriological isolation and identification was done on specific media for S.aureus (sheep blood agar, manitol agar and brain heart infusion agar), specific media for Strept. agalacia (Edward media), and specific media for E-coli and coliforms (MacConky agar) according to (Toply and Welson 1998). Identification of the isolated organisms was done according to (APHA 1992, Koneman et al., 1992, Collee et al., 1996 and Quinn et al., 2002) based on their colony morphology, hemolytic pattern on blood agar, microscopic examination (Gram staining) and biochemically for glucose, sucrose and maltose fermentation, catalase activity, gelatine liquefaction, urea production, methyl red and nitrate reduction were adopted.

\section{Antimicrobial sensitivity test :}

All the bacteria isolated through microbiological procedures were subjected to antimicrobial susceptibility testing by disc diffusion method (Anonymous, 2004). The sensitivity against Gentamycin10Ug, Ceprofloxacin 5Ug, Chloramphenicol 30Ug, Cephalothin 30Ug, Sulphtrim10Ug, Amoxycillin 25Ug, Lincomycin 10Ug, 
Oxytetracycline 30Ug, Novobiocin 10Ug, Erythromycin 5Ug, Ampiclox30Ug and Pencillin G30Ugwas determined on Muellar-Hinton agar as described by National Committee for Clinical Laboratory Standards

\section{DNA Extraction:}

Milk samples were mixed and a 300- $\mu$ l sample added to $300 \mu \mathrm{l}$ of lysis buffer $(0.1 \mathrm{M} \mathrm{NaCl}, 20 \mathrm{mM}$ Tris$\mathrm{HCl}, 1 \mathrm{mM}$ EDTA, $0.5 \%$ SDS and $100 \mu \mathrm{g}$ of proteinase $\mathrm{K} / \mathrm{ml}$ ). After incubation at $37^{\circ} \mathrm{C}$ for $4 \mathrm{~h}$. DNA was extracted and purified using phenolchloroform method as described previously by (Sambrook et al., 1989). The dried DNA pellet was dissolved in $50 \mu \mathrm{l}$ of TE buffer $(10 \mathrm{mM}$ Tris $\mathrm{HCl}-1$ mM EDTA, $\mathrm{pH} 7.8$ ) and stored at $-20^{\circ} \mathrm{C}$ until used.

\section{Oligonucleotide Primers:}

Primers were synthesized, by (Fermentas, AB.Gene), (MWG, oligosynthesis - Germany). The sequences of different primers (Riffon et al., 2001) included Staphylococcus aureus specific primer (Forward: 5 GGA CGA CAT TAG ACG AAT CA 3` and reverse: 5 CGG GCA CCT ATT TTC TAT CT 3'); Escherichia coli specific primer (Forward: 5 ATC AAC CGA GAT TCCAGT 3`and reverse: 5' TCA CTA TCG GTC AGT CAG GAG 3`) and Streptococcus agalactiae specific primer (Forward: 5 ` CGC TGAGGT TTG GTG TTT ACA 3`and reverse: $5{ }^{\prime}$ CAC TCC TAC CAA CGT TCT TC $3{ }^{`}$ ).

\section{PCR Assays:}

Simplex PCR assay for amplification of each organism was performed using $25 \mu \mathrm{l}$ PCR reaction volume. $12.5 \mu \mathrm{l}$ of $2 \mathrm{X}$ PCR master mix (Fermentas, Germany), $150 \mathrm{ng}$ of the DNA template, $0.5 \mu \mathrm{M}$ of each primer and Up to $25 \mu 1$ Nuclease free water were mixed in a PCR tube. The amplification was performed in a programmable heating block, (Primus Thermal Cycler, MWG Biotech, Germany). A total of 35 PCR cycles were run under the following conditions; denaturation at $94^{\circ} \mathrm{C}$ for $45 \mathrm{sec}$, annealing for $1 \mathrm{~min}$ (at 64 and $60^{\circ} \mathrm{C}$ for Staphylococcus aureus \& Escherichia coli and Streptococcus agalactiae, respectively) and extension at $72^{\circ} \mathrm{C}$ for 2 min. After final cycle the preparations were kept for $10 \mathrm{~min}$ at $72^{\circ} \mathrm{C}$ to complete the reaction.

A one step multiplex PCR was developed using each of the primer sets previously used for the simplex PCR. $25 \mu \mathrm{l}$ PCR reaction volume containing $12.5 \mu 1$ of 2X PCR master mix (Fermentas, Germany), 0.5 $\mathrm{mM} \mathrm{MgCl}, 250 \mathrm{ng}$ of the DNA template, $25 \mathrm{pmol}$ of each primer and Up to $25 \mu 1$ Nuclease free water were mixed in a PCR tube. A total of 40 PCR cycles were run under the following conditions; denaturation at $94^{\circ} \mathrm{C}$ for $45 \mathrm{sec}$, annealing for $1 \mathrm{~min}$ at $62^{\circ} \mathrm{C}$ and extension at $72^{\circ} \mathrm{C}$ for $2 \mathrm{~min}$. After final cycle the preparations were kept for $10 \mathrm{~min}$ at $72^{\circ} \mathrm{C}$.

Amplification products were electrophoresed in $1.7 \%$ agarose gel containing $0.5 \mathrm{X} \mathrm{TBE}$ at 70 volts for 60 min. and visualized under ultraviolet light. To assure that the amplification products were of the expected size, a 100 bp DNA ladder was run simultaneously as a marker. Presence of 1318 bp, 232 bp and 405 bp DNA fragments indicated the presence of Staphylococcus aureus, Escherichia coli and Streptococcus agalactiae DNA, respectively.

\section{Statistical analysis}

The cumulative data was entered in Microsoft Excel for analysis of the data, and $\mathrm{P}<0.05$ was regarded as significant. Incidence risks of clinical mastitis were computed by dividing the number of occurrences of clinical mastitis during a defined period by average number of lactating cows during that period. The seasonal variation of clinical mastitis incidence was tested with Edward's test corrected for changing size of the population at risk in different months Norusis M J (1993).

\section{RESULTS}

Table 1: Clinical examination of udder and milk secretion in healthy and diseased buffaloes.

\begin{tabular}{cccc}
\hline & Udder & Milk & (by necked eye) \\
\hline Size & 81 animals had symmetrical udder- & Normal milk & 104 \\
& 23 asymmetrical & & 8 \\
shape & 81 normal key shape- 10 abdominal- & Milk with watery appearance & \\
\hline Teat tip & 7 round- 6 stepped & Milk with bloody appearance & 5 \\
\hline Skin & 81 normal pale red -23 hyperemic & Milk with mucous & 6 \\
\hline Surrounding tissue & 94 normal-10 with scars & Milk with flakes & 4 \\
\hline
\end{tabular}


Table 2: Incidence of clinical and subclinical mastitis in examined buffaloes.

\begin{tabular}{ccccccc}
\hline & $\begin{array}{c}\text { No. of affected } \\
\text { animals }\end{array}$ & $\%$ & $\begin{array}{c}\text { No. of examined } \\
\text { quarters }\end{array}$ & $\%$ & $\begin{array}{c}\text { No. of affected } \\
\text { quarters }\end{array}$ & $\%$ \\
\hline Clinical mastitis & 23 & 22.1 & 92 & 22.1 & 56 & 13.4 \\
\hline Sub clinical mastitis & 28 & 26.9 & 112 & 26.9 & 68 & 16.3 \\
\hline Healthy & 53 & 51.0 & 212 & 51.0 & 292 & 70.3 \\
\hline total & 104 & 100 & 416 & 100 & 416 & 100 \\
\hline
\end{tabular}

Table 3: The distribution of infected quarters in the clinically and subclinically mastitic buffaloes.

\begin{tabular}{|c|c|c|c|c|c|}
\hline \multirow[b]{2}{*}{$\begin{array}{l}\text { Lactation } \\
\text { Season }\end{array}$} & \multirow{2}{*}{$\begin{array}{r}\text { No. of animals } \\
\text { at risk }\end{array}$} & \multicolumn{2}{|c|}{ Clinical mastitis } & \multicolumn{2}{|c|}{ Sub clinical mastitis } \\
\hline & & $\begin{array}{l}\text { No. of diseased } \\
\text { animals }\end{array}$ & $\%$ & $\begin{array}{l}\text { No. of diseased } \\
\text { animals No. }\end{array}$ & $\%$ \\
\hline 1 & 20 & 3 & 15.0 & 4 & 20.0 \\
\hline 2 & 27 & 4 & 14.8 & 5 & 18.5 \\
\hline 3 & 35 & 10 & 28.6 & 12 & 35.3 \\
\hline 4 & 22 & 6 & 27.3 & 7 & 31.8 \\
\hline $\begin{array}{c}\text { Total of diseased } \\
\text { animals }\end{array}$ & 104 & 23 & 22.1 & 28 & 26.9 \\
\hline
\end{tabular}

*1st lactation season means a buffalo has 3 years old- $\quad$ *2nd lactation season means a buffalo has 4 years old

*3rd lactation season means a buffalo has 5 years old _ - *4th lactation season means a buffalo has 6 years

Table 4: The effect of lactation season on mastitis incidence in examined buffaloes.

\begin{tabular}{|c|c|c|c|c|c|c|c|c|c|c|}
\hline \multirow[t]{2}{*}{$\begin{array}{c}\text { No of } \\
\text { animals } \\
\text { Studied }\end{array}$} & \multirow[t]{2}{*}{$\begin{array}{l}\text { Type of } \\
\text { Mastitis }\end{array}$} & \multirow[t]{2}{*}{$\begin{array}{l}\text { Total affected } \\
\text { animals }\end{array}$} & \multicolumn{2}{|c|}{ One quarter } & \multicolumn{2}{|c|}{$\begin{array}{c}\text { two } \\
\text { quarters }\end{array}$} & \multicolumn{2}{|c|}{$\begin{array}{l}\text { Three } \\
\text { quarters }\end{array}$} & \multirow[t]{2}{*}{$\begin{array}{c}\text { Four } \\
\text { quarters }\end{array}$} & \multirow[b]{2}{*}{$\%$} \\
\hline & & & No. & $\%$ & No. & $\%$ & No. & $\%$ & & \\
\hline \multirow[t]{2}{*}{104} & Clinical & 23 & 7 & 30.4 & 5 & 21.7 & 5 & 21.7 & 6 & 26.2 \\
\hline & Sub clinical & 28 & 10 & 35.7 & 4 & 14.3 & 6 & 21.4 & 8 & 28.6 \\
\hline
\end{tabular}

Table 5: Detection of S. aureus, E. coli and St. agalactiae in 124 milk samples by culture, simplex PCR and multiplex PCR Test method

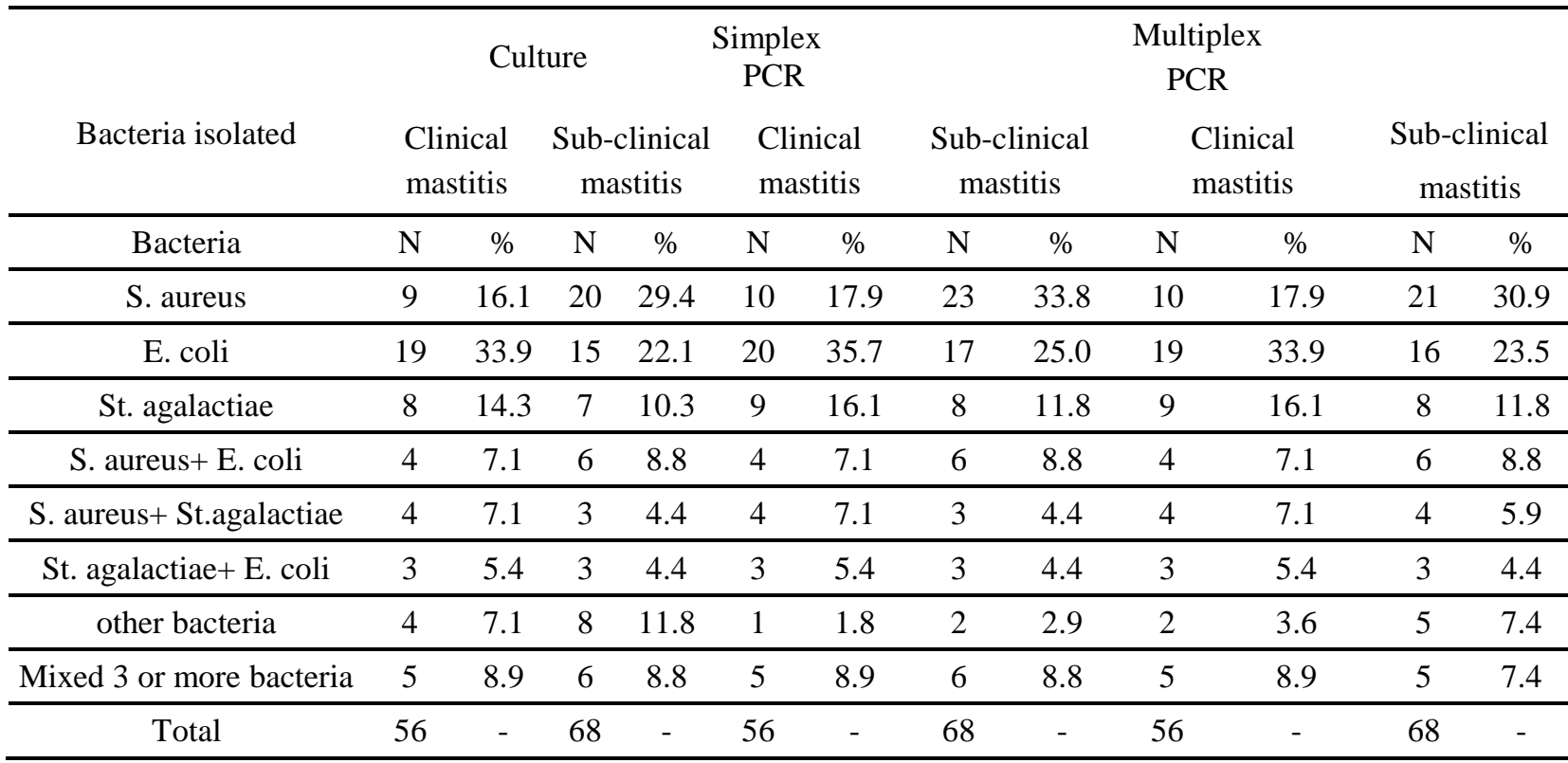


Table 6: In vitro sensitivity of different microorganisms to different antibiotics

\begin{tabular}{ccccc}
\hline Antibiotics & & $\begin{array}{c}\text { Staphylococcus } \\
\text { aureus(No:46) }\end{array}$ & $\begin{array}{c}\text { Streptococcus } \\
\text { agalactiae(No:28) }\end{array}$ & $\begin{array}{c}\text { E. coli } \\
\text { (No:50) }\end{array}$ \\
\hline Gentamycin & $10 \mathrm{Ug}$ & +++ & +++ & +++ \\
\hline Ceprofloxacin & $5 \mathrm{Ug}$ & +++ & +++ & +++ \\
\hline Chloramphenicol & $30 \mathrm{Ug}$ & ++ & +++ & +++ \\
\hline Cephalothin & $30 \mathrm{Ug}$ & ++ & +++ & +++ \\
\hline Sulph-trim. & $10 \mathrm{Ug}$ & ++ & ++ & +++ \\
\hline Amoxycillin & $25 \mathrm{Ug}$ & ++ & + & ++ \\
\hline Lincomycin & $10 \mathrm{Ug}$ & +++ & +++ & ++ \\
\hline Oxytetracycline & $30 \mathrm{Ug}$ & ++ & ++ & + \\
\hline Novobiocin & $10 \mathrm{Ug}$ & +++ & ++ & + \\
\hline Erythromycin & $5 \mathrm{Ug}$ & ++ & ++ & + \\
\hline Ampiclox & $30 \mathrm{Ug}$ & + & +++ & + \\
\hline Pencillin G & $30 \mathrm{Ug}$ & + & + & + \\
\hline
\end{tabular}

Table 7: Correlation between SCC / $\mathrm{ml}$. and single bacterial infection in the examined milk sample.

\begin{tabular}{ccccc}
\hline Bacterial infection & Minimum SCC / ml & Maximum SCC / ml & Mean & \pm SEM \\
\hline Staphylococcus aureus & 13000 & 200000 & 28420.6897 & 8835.53810 \\
\hline Escherichia coli & 320000 & 320000 & 102805.8824 & 16195.05324 \\
\hline $\begin{array}{c}\text { Streptococcus } \\
\text { agalactiae }\end{array}$ & 13000 & 17000 & 14500 & 284.52132 \\
\hline
\end{tabular}

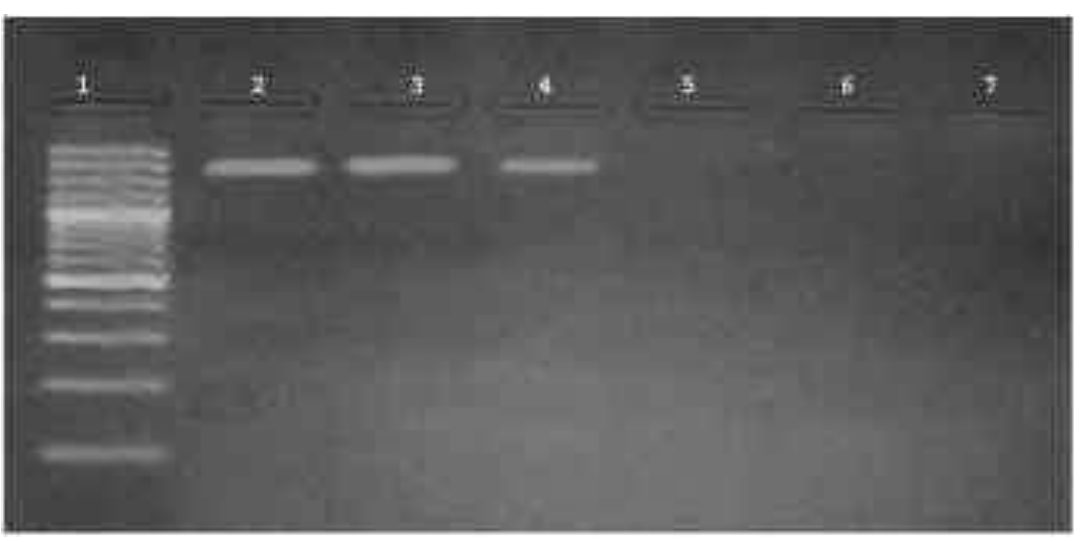

Fig. 1: Polymerase chain reaction products (1318 bp) amplified from Staphylococcus aureus DNA. Lane 3, positive clinical mastitic milk sample; Lane 4, positive sub-clinical mastitic milk sample. Lane 5, negative clinical mastitic milk sample; Lane 6, negative sub-clinical mastitic milk sample. Lane 2, Control positive; Lane 7, Control negative and Lane 1, 100 bp DNA marker

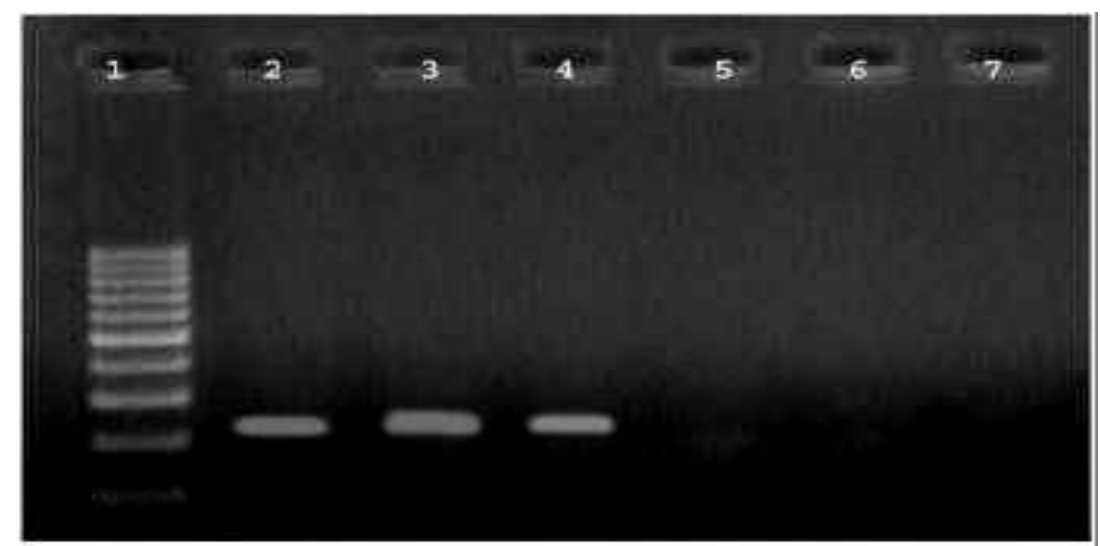

Fig. 2: PCR products (232 bp) amplified from Escherichia coli DNA. Lane 3, positive clinical mastitic milk sample; Lane 4, positive sub-clinical mastitic milk sample. Lane 5, negative clinical mastitic milk sample; Lane 6, negative sub-clinical mastitic milk sample. Lane 2, Control positive; Lane 7, Negative control and Lane 1, 100 bp DNA marker. 


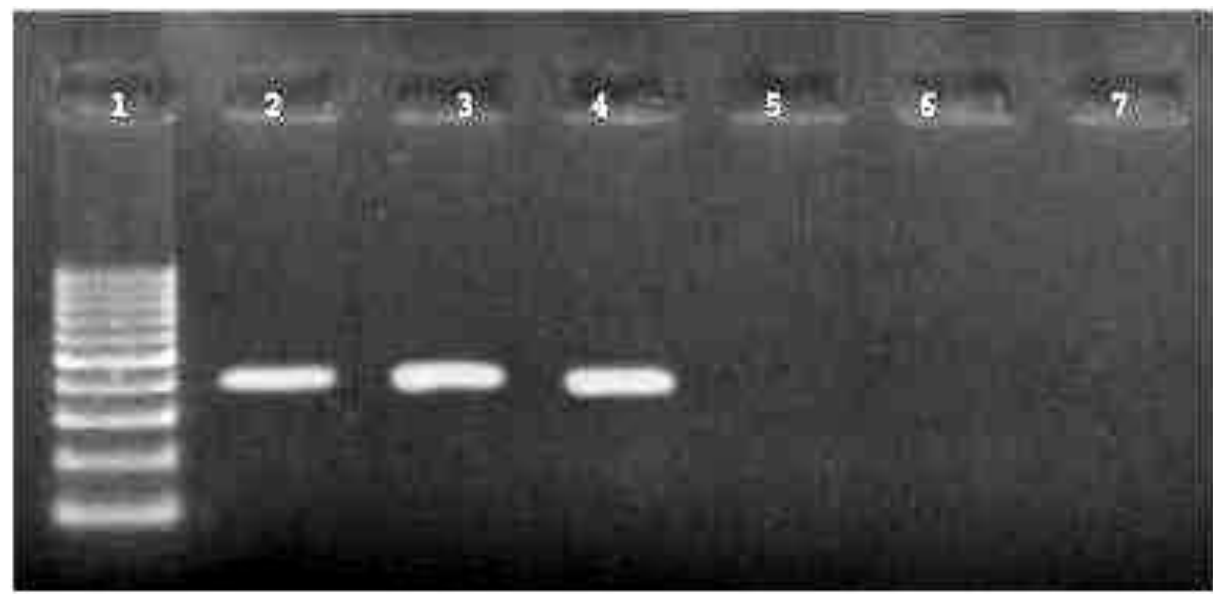

Fig. 3: PCR products (405 bp) amplified from Streptococcus agalactiae DNA from: Lane 3, positive clinical mastitic milk sample; Lane 4, positive sub-clinical mastitic milk sample. Lane 5, negative clinical mastitic milk sample; Lane 6, negative sub-clinical mastitic milk sample. Lane 2, Control positive; Lane 7, Negative control and Lane 1,100 bp DNA marker

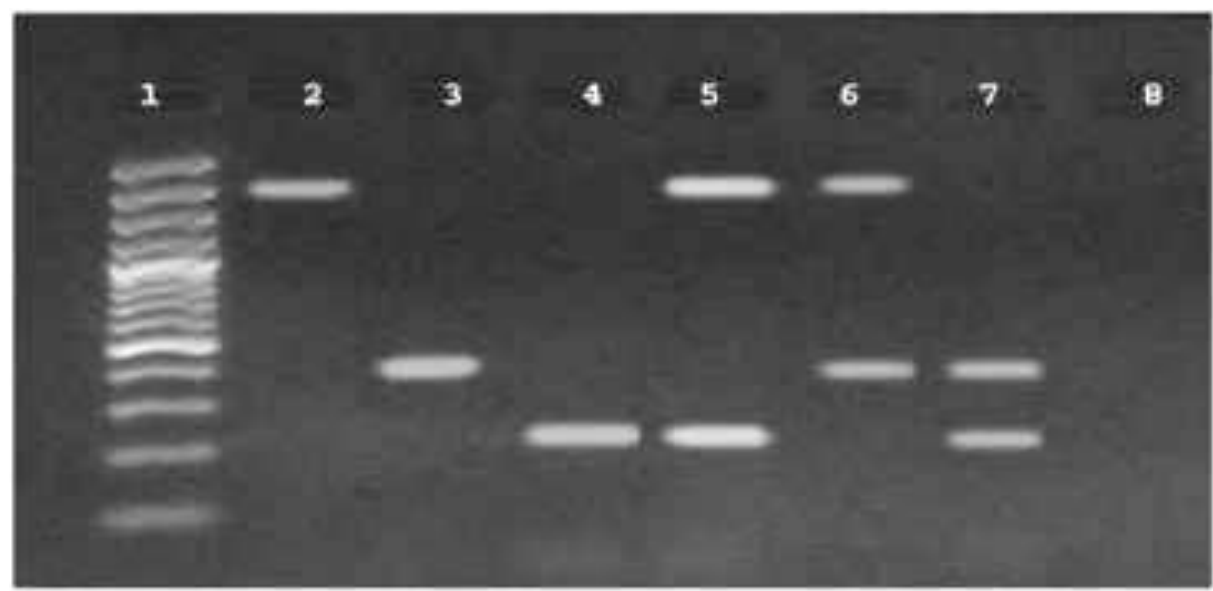

Fig. 4: Multiplex PCR products amplified from DNA. Lane 2, Staphylococcus aureus; Lane 3, Streptococcus agalactiae; Lane 4, Escherichia coli; Lane 5, Staphylococcus aureus and Escherichia coli; Lane 6, Staphylococcus aureus and Streptococcus agalactiae; Lane 7, Streptococcus agalactiae and Escherichia coli. Lane 1, 100 bp DNA marker and Lane 8, Negative control.

\section{DISCUSSION}

Mastitis is a global problem as it adversely affects animal health, quality of milk and economics of milk production and every country including developed ones suffer huge financial losses (Sharma et al., 2007).

In the present study table (1) results revealed that by inspection and palpation the udder of examined animals were asymmetrical size in 23 cases, the tip were pointed in 15 cases, the skin were hyperemic in 23 cases and 10 animals had scars on surrounding tissue. This agreed with (Yasser et al., 2013) who suggested that abnormal udder shape could be considered as predisposing factor to mastitis. Examination of milk by necked eye showed that 4 cases had flakes, milk with bloody appearance were seen in 5 cases and milk with mucous were seen in 6 cases. In mastitis, there is drastic change in the milk, taste and consistency. Muhammad et al. (2005) also recorded that the changes in the milk due to mastitis are shown as milk with bad taste and odor was found $8.08 \%$ in buffalo and $6.74 \%$ in cow. Milk mixed with mucus and blood was recorded $6.61 \%$ and $7.35 \%$ in buffalo and in cow $7.35 \%$ and $5.61 \%$ while milk with mixed mucus and blood was $5.51 \%$ in buffalo and $4.49 \%$ in cow, respectively.

The results obtained in table (2) revealed that from 104 animals examined the prevalence of clinical mastitis in buffaloes were recorded in 23 animals by ratio of $(22.1 \%)$. These findings are in close alignment with the findings of (Bilal et al., 2004). The prevalence of sub-clinical mastitis was also found higher in buffaloes that reported in 28 animals by ratio of $26.9 \%$ which agree with (Dangore et al., 2000).

There was a large variation in the prevalence of clinical and subclinical mastitis rates which may be 
attributed to some mangemental factors such as using of dry buffaloes therapy, feeding patterns, heifer replacement rates, environmental condition surroundings the animals, prevalent microorganism (McDougall et al., 2014).

Table (3) the higher incidence of clinical mastitis and subclinical mastitis in one quarters then four quarters by ratio of $30.4 \%, 35.7 \%, 26.2 \%$ and $28.6 \%$ respectively were recorded as also by (Didonet et al., 1986 and Karimuribo et al., 2006). Nakov and Trajcev (2012) also reported that in the most cases of clinical mastitis there was affected only one quarter of the mammary gland $(74.35 \%)$, two quarters in $20.13 \%$, three quarters to $3.61 \%$ and four quarters were affected in $1.89 \%$ of the cases of clinical mastitis.

As shown in table (4) the ratio of the clinical mastitis was $15 \%$ in the $1^{\text {st }}$ lactation season of the examined animals, $14.8 \%$ in the $2^{\text {nd }}$ lactation season, $28.6 \%$ in the $3^{\text {rd }}$ lactation season and $27.3 \%$ in the $4^{\text {th }}$ lactation season while the percent of sub clinical mastitis was $20.0 \%, 18.5 \%, 35.3 \%$ and $31.8 \%$ in the $1^{\text {st }}, 2^{\text {nd }}, 3^{\text {rd }}$, and $4^{\text {th }}$ lactation season respectively, the result obtained are going hand by hand with (Pal and Verma 1988 and Alam et al., 2004) who reported the highest incidence at 3rd calving, and agree with (Kavitha et al., 2009 and Sharma et al., 2004) who found that, As the parity increases, an increase in the incidence of mastitis is seen (also found higher prevalence of subclinical mastitis in 5 to 9 years old animals and in 3rd and 4th parities. The difference found among reports may be due to various factors such as breed, season, and husbandry system (Moroni et al., 2006).

Most of the mastitis cases are of infectious etiology (Deb et al. 2013). Table (5) Out of the 56 milk samples collected from clinical cases and examined bacteriologically; Staphylococcus aureus, Escherichia coli and Streptococcus agalactiae were recovered and identified in percentages of $16.1 \%$, $33.9 \%$ and $14.3 \%$, respectively. Dual bacterial isolation [Staphylococcus aureus and Escherichia coli (7.1\%); Staphylococcus aureus and Streptococcus agalactiae (7.1\%); Streptococcus agalactiae and Escherichia coli $(5.4 \%)$ ] was also detected. Negative samples revealed $7.1 \%$ and $8.9 \%$ revealed mixed cultures of three or more environmental bacteria and accordingly were considered contaminated. On the other hand, the 68 milk samples from sub-clinical cases were examined bacteriologically. Bacterial isolates were identified as Staphylococcus aureus (29.4\%), Escherichia coli $(22.1 \%)$ and Streptococcus agalactiae (10.3\%). Dual bacterial isolation [Staphylococcus aureus and Escherichia coli (8.8\%); Staphylococcus aureus and Streptococcus agalactiae (4.4\%); and Streptococcus agalactiae and Escherichia coli (4.4\%)] was also detected. Also, 11.8 and $8.8 \%$ of samples revealed negative and mixed cultures of three or more environmental bacteria, respectively. The results presented here are similar to previous studies by (Döpfer et al.,1999 and $\mathrm{Su}$, et al.,2000).

The number of mastitic milk samples positive for selected major pathogens of mastitis in the individual simplex PCR assays is listed in table 5. The reactivity of used primer sets with Staphylococcus aureus, Escherichia coli and Streptococcus agalactiae in mastitic milk samples is shown in Figures 1, 2 and 3, respectively. The results indicated that, out of 56 milk samples from clinical cases of mastitis, 17.9, 35.7 and $16.1 \%$ of the samples were reacted positive when tested using Staphylococcus aureus, Escherichia coli and Streptococcus agalactiae specific primer sets, respectively. On the other hand, out of $68 \mathrm{milk}$ samples from sub -clinical cases of mastitis, $33.8 \%$, $25.0 \%$ and $11.8 \%$ of the samples were reacted positive when tested using Staphylococcus aureus, Escherichia coli and Streptococcus agalactiae specific primer sets, respectively. Dual bacterial detection [Staphylococcus aureus and Escherichia coli (7.1\%); Staphylococcus aureus and Streptococcus agalactiae (7.1\%); and Streptococcus agalactiae and Escherichia coli (5.4\%)] were also indicated in samples from clinical mastitic cows and $8.8,4.4$ and $4.4 \%$, respectively, in samples from subclinical mastitic cows. Also, 1.8 and $2.9 \%$ samples were negative in samples from clinical and subclinical mastitic cows, respectively which agree with (Zadoks and Schukken 2006).

The data in table 5 and Figure 4 also showed the results of multiplex PCR using different primer sets of Staphylococcus aureus, Escherichia coli and Streptococcus agalactiae. Out of 56 milk samples from clinical cases of mastitis, 17.9, 33.9 and $16.1 \%$ of the samples were reacted positive, respectively. On the other hand, out of 68 milk samples from subclinical cases of mastitis, 30.9, 23.5 and $11.8 \%$ of the samples were reacted positive, respectively. Dual bacterial detection [Staphylococcus aureus and E. coli (7.1\%); Staphylococcus aureus and Streptococcus agalactiae $(7.1 \%)$; and Streptococcus agalactiae and Escherichia coli $(5.4 \%)]$ was also indicated in samples from clinical mastitic cows and 8.8, 5.9 and $4.4 \%$, respectively, in samples from sub-clinical mastitic cows. Also, 3.6 and $7.4 \%$ samples revealed negative in samples from clinical and sub-clinical mastitic cows, respectively. Phuektes et al. (2003) reported the same results. The obtained result are parallel to result obtained by (Abd-Elrahman 2013), who found that $S$. aureus, E. coli, St agalactia and St. dysgalactia were the most common isolates in clinical mastitis. E. coli, S. aureus, C.N.S, Pseudomonas, St agalactia, and St. dysgalactia were the most common isolates in subclinical mastitis.

In table (6) Antibiogram profile using 12 different antibiotics revealed that the most isolates of Staphylococcus aureus were highly sensitive to gentamycin cebrofloxacin, lincomycin, and 
novobiocin That similar results were obtained by (İkiz et al., 2013). These organisms showed less sensitivity to Chloramphenicol, Cephalothin, Sulphtrim., Amoxycillin, Oxytetracycline, Erythromycin, Ampiclox and Pencillin G. Abdel - Khalek and ElSherbini (2005) their results suggest that Penicillin is no longer the antimicrobial of choice for staphylococcal mastitis. Sensitivity of Streptococcus spp. To gentamycin cebrofloxacin, chloramphenicol, cephalothin, oxytetracycline and penicillin $G$ were very high in this study but Sulph-trim, Amoxycillin, Lincomycin Novobiocin, Erythromycin and Ampiclox were less sensitive (Abd El-Hafeez, 2002). E.coli were highly sensitive to gentamycin, ciprofloxacin, chloramphenicol, sulfa-trim and amoxycilline. The obtained results were agreed with (CLSI. 2008). But Cephalothin, Lincomycin, Oxytetracycline, Novobiocin, Erythromycin, Ampiclox and Pencillin $G$ were less sensitive as shown in (Table 5). Rehman (1995) and Rocha et al. (2014) also observed same sensitivity of E.coli.

In table (7) the inflammatory reaction caused by intra-mammary infection is most commonly measured as an increase in SCC. The samples which contained single infection with Escherichia coli recorded the highest mean SCC (102805.8824 \pm 16195.05324$)$, in case of Streptococcus agalactiae, the samples recorded the lowest mean SCC (14500 \pm 284.52132$)$, while the samples containing Staphylococcus aureus recorded an intermediate mean SCC (28420.6897 \pm 8835.5381$)$. These results substantiate with (Middleton et al., 2004) and disagree with (De Haas et al., 2004) who noted that clinical E. coli mastitis was significantly associated with the presence of a short peak in SCC, whereas Staph. aureus was associated with long increased SCC. Streptococcus dysgalactiae was not strongly associated with any of the defined patterns of peaks in SCC.

\section{CONCLUSION}

The dairy livestock of Sohag governorate were suffering a large prevalence of clinical and subclinical mastitis which unnoticed and very fewer farmers were aware of it. The staphyloccal mastitis was predominant for the infectious cause followed by coliform and streptococcal spp. From this study, it is concluded that the Gentamycin Ceprofloxacin, Lincomycin and Novobiocin are the most sensitive chemotherapeutic agents where the dairy animal management was poor. Due to limitation of cultural methods, PCR assays can be used as a rapid, sensitive and specific routinely diagnostic tool to detect the presence of Staphylococcus aureus, Escherichia coli and Streptococcus agalactiae in milk samples.

\section{RECOMMENDATIONS}

1) Health care of the teats beside the cleanliness of animal pens.
2) Treatment of cases of clinical mastitis

3) Treatment of animals during the period of dryness (55 - 60 days before birth).

4) Elimination of cattle infections chronic fever.

5) it is mandatory that antibiogram study is made from time to time in a locality to be on the lookout of the most effective drug against the prevailing mastitogens i.e., bacteria.

6) Treatment of cases of hoof infection, especially in cattle public. Which can lead to inflammation in the udder or uterus.

7) The farmers should be inspired for mastitis management, udder health management, shed management and nutrition management through training, workshops, tours, farmers' schools for hygienic milk production in commercial scale

\section{REFERENCES}

Abd- Elrahman Amir Hamed (2013): Mastitis in housed dairy buffaloes: incidence, etiology, clinical finding, antimicrobial sensitivity and different medical treatment against E. coli mastitis. Life Science Journal; 10 (1).

Abd El-Hafeez, M.M. (2002): In vitro antimicrobial susceptibility and resistance pattern of Staphylococcus spp. recovered from bovine mastitis . Int. Conf. for Develop. And the Env. In Arab World, March, 26-28, 21-32.

Abdel-Khalek, A. and El-Sherbini, M. (2005): Prevelence of contagious pathogens of bovine subclinical mastitis and relationship to bacterial and somatic cel counts. $4^{\text {th }}$ Int. Sci. Conf., Mansoura, 1-10.

Alam Zeb Khan; Ahmad Khan; C.S. Hayat; Z. Munir and Umer Ayaz (2004): Prevalence of Mastitis in Buffaloes and Antibiotics Sensitivity Profiles of Isolates. Gomal College of Veterinary Sciences, Gomal University, D.I. Khan, Pakistan Pak. j. life soc. sci, 2 (1) : 7375.

Alekish, M.O.; Alshehabat, M.A. and Abutarbush, S.M. (2014): The prevalence and etiology of subclinical mastitis in Awassi sheep; emphasis on the relationship between the isolated organisms and the somatic cell count. European Journal of Veterinary Medicine. 8: $1-13$.

APHA (American Public Health association) (1992): Standard method for the examination of dairy products. 16th Ed., New York.

Andrei, S.; Matei, S.; Fit, N.; Cernea, C.; Ciupe, S.; Bogdan, S. and Groza, I.S. (2011): Glutathione peroxidase activity and its relation with somatic cell count number of colony forming units and protein content in subclinical mastitis cow milk. Romanian Biotechnological letters. Vol. 16, No. 3: 62096217.

Anonymous (2004): Manual of Diagnostic Tests and Vaccines for Terrestrial Animals (mammals, birds and bees). Vol. 1. France.103-104. 
Bilal, M.Q.; Iqbal, M.U.; Muhammad, G.; Avais, M. and Sajed, M.S. (2004): Factors affecting clinical mastitis in buffaloes around Faisalabad district (Pakistan). Int. J. Agric. Biol., 6: 185189.

CLSI. (2008): Performance standards for antimicrobial disk and dilution susceptibility tests for bacteria isolated from animals: approved standard. M31-A3, 3rd ed.Wayne, PA: CLSI.

Collee, J.G.; Miles, R.S. and Wan, B. (1996): Tests for identification of bacteria. In Mackie and mac Cartney, s Practical Medical Microbiology, 14 the edn, app.131-150. Edited by collee, J.G.; Fraser A.G.; Marimon, B.P. and Simmons, a New York: Churchill Livingstone.

Dangore, A.D.; Bhalerao, D.P.; Jagadish, S.; Keskar, D.V. and Sharma, L.K. (2000): Evaluation of some byre-side tests in bovine subclinical mastitis. Indian Vet. J., 77: 380-381

De Haas, Y.; Veerkamp, R.; Barkema, H.; Grohn, Y. and Schukken, Y. (2004): Associations between pathogen-specific cases of clinical mastitis and somatic cell count patterns. J. Dairy Sci., 87(1): 95-105.

Deb, R.; Kumar, A. and Chakraborty, S. (2013): Trends in diagnosis and control of bovine mastitis: A review. Pak. J. Biol. Sci. 16(23): 1653-1661.doi: 10.3923/pjbs.2013.1653.1661

Didonet, L.H.; Singh, N.P. and Justiniani, H.H. (1986): Comparison of indirect tests for diagnosis of sub clinical mastitis in buffaloes. Bull. de Pessqvisa Centro de Pessqvisa Agropecvaria do Tropico UmidoEMBRAPA Brazil, No. 77, 13 pp. (Vet. Bull. Abst. 5060, 1989).

Döpfer, D.; Barkema, H.W.; Lam, G.M.; Schukken, Y.H. and Gaastra, W. (1999): Recurrent clinical mastitis caused by Escherichia coli in dairy cows. J. Dairy Sci., 82: 80-85.

Galiero, G. (2002): The control of environmental mastitis. Bubalusbubalis I: 26-28.

Gonzalez, R.N.; Jasper, D.E.; Kronlund, N.C.; Farver, T.B.; Cullor, J.S.; Bushnell, R.B. and Dellinger, J.D. (1990): Clinical mastitis in two California dairy herds participating in contagious mastitis control programs. J. Dairy Sci. 73: 648-660.

Hussain, R.; Javed, M.T.; Khan, A.; Mahmood, F. and Kausar, R. (2012): Mastitis and associated histo-pathological consequences in the context of udder morphology. Int. J. Agric. Biol.14: 947-952.

Hussain, R.; Khan, A.; Javed, M.T. and Ali, F. (2013): Morphometric and pathological studies on mammary gland of slaughtered Nili-Ravi buffaloes. Pak. J. Agric. Sci. 50: 123-130.

İkiz, S.; Saran, BB.; Bingöl, EB.; Çetin, Ö.; Kaşikçi,

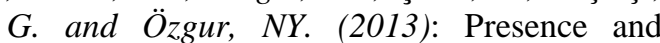

antibiotic susceptibility patterns of contagious mastitis agents (Staphylococcus aureusand Streptococcus agalactiae) isolated from milks of dairy cows with subclinical mastitis.; 37: 569-574.

International Dairy Federation (1987): Bovine Mastitis Definitions and Guidelines for Diagnosis, vol. 211. International Dairy Federation, Brussels, Belgium, 3-8.

Karimuribo, E.D.; Fitzpatrick, J.L.; Bell, C.E.; Swai, E.S.; Kambarage, D.M.; Ogden, N.H.; Bryant, M.J. and French, N.P. (2006): Clinical and subclinical mastitis in smallholder dairy farms in Tanzania: Risk, intervention and knowledge transfer. Preventive veterinary medicine 74 , 83-98.

Kavitha, KL.; Rajesh, K.; Suresh, K.; Satheesh, K. and Sundar, NS. (2009): Buffalo mastitis - risk factors. Buffalo Bull, 28: 135-137.

Koneman, E.W.; Allen, S.D.; Janda, W.M.; Schreckenberger, P.C. and Winn, W.C. (1992): Packaged in kit identification system. Color atlas and textbook of diagnostic microbiology. Koneman, E.W. (Eds.), 4th Ed., B. Lippincott Co., Phliladelphia, PA., pp: 163170.

Lalrintluanga, C.; Ralte, E.L. and Markunga, H. (2003.): Incidence of mastitis, bacteriology and antibiogram in dairy cattle in Aizawl, Mizoram. Indian Vet. J., 80: 931-932

McDougall, S.; Hussein, H. and Petrovski, K. (2014): Antimicrobial resistance in Staphylococcus aureus, Streptococcus uberis and Streptococcus dysgalactiae from dairy cows with mastitis. The New Zealand Veterinary Journal, 62 (2): 68-76.

Metry (1996): Buffalo. The main dairy animal in Egypt. Booklet, Academy of Scientific Research and Technology.

Middleton, J.; Hardin, D.; Steevens, B.; Randle, R. and Tyler, J. (2004): Use of somatic cell count and California mastitis test from individual quarter milk samples to detect subclinical intramammary infection in dairy cattle from a herd with a high bulk tank somatic cell count. J. Am. Vet. Med. Assoc., 224(3): 419-423.

Moroni, P.; Sgoifo Rossi, C.; Pisoni, G.; Bronzo, V.; Castiglioni, B. and Boettcher, P.J. (2006): Relationships between somatic cellcount and intramammary infection in buffaloes. J. Dairy Sci. 89 (3): 998-1003.

Muhammad, G., Khan, M.Z.; Attar, M. and Sajjad-ur Rahman (2005): Clinico-epidemiological and therapeutic observations on pox outbreak in small holder dairy farms. Buffalo J., 2: 259267.

Nakov Dimitar and Trajcev Metodija (2012): Udder quareter risk facteors associated with prevalence of bovine clinical mastitis, Mac Vet. Rev. 2012; 35 (2): 55-64. 
Norusis, M.J. (1993): SPSS for Windows, 7.5 Ed SPSS Inc., Chicago, IL

Pal, B. and Verma, B.B. (1988): Preliminary trials with kanamycin acid sulphate in the treatment of subclinical mastitis in buffaloes. Indian Vet. J. 65: 346-347.

Philip M., Sear; Ruben N.; Gonzalez; David J., Wilson and Hong R. (1993): Procedures for mastitis diagnosis and control. In the Vet. Clinics of North America: Food Animal Practice: Update of Bovine mastitis Vol. 9 No. 3. p 445

Phuektes, P.; Browning, G.; Anderson, G. and Mansell, P. (2003): Multiplex polymerase chain reaction as a mastitis screening test for Staphylococcus aureus, Streptococcus agalactiae, Streptococcus dysgalactiaeand Streptococcus uberisin bulk milk samples. J Dairy Res. 70: 149-155.

Pradhan, P.; Gopinath, S.M.; Reddy, G.R.; Dechamma, H. and Suryanarayana, V.V.S. (2011): Detection of major pathogens in bovine subclinical mastitis by multiplex PCR directly from milk samples in presence of an internal control. Journal of Fundamental and Applied Life Science. Vol (1): 209-218.

Quinn, P.j.; Markey, B.K.; Carter, M.E.; Donnelly, W.J.C.; Leonard, F.C. and Maguire. (2002): Veterinary microbiology and microbial diseases.1st Blackwell Science 1sted.

Rehman, F.U. (1995): Study on: (i) evaluation of SURF FIELD MASTITIS TEST for the detection of subclinical mastitis in buffaloes and cattle, and antibiotic susceptibility of the pathogens. M. Sc. Thesis, Deptt. Vet. Clinical Medicine and Surgery, Univ. Agri., Faisalabad.

Reyher, K.K. and Dohoo, I.R. (2011): Diagnosing intramammary infections: Evaluation of composite milk samples to detect intramammary infections. J. Dairy Sci., 94: 3387-3396.

Riffon, R.; Sayasith, K.; Khalil, H.; Dubreuil, P.; Drolet. M. and Lagacé, J. (2001): Development of a rapid and sensitive test for identification of major pathogens in bovine mastitis by PCR. J. Clinical Microbiol., 39(7): 2584-2589.

Rocha, B.; Mendonça, D. and Niza-Ribeiro, J. (2014): Trends in Antibacterial Resistance of Major Bovine Mastitis Pathogens in Portugal. RCPV. 109: 79-88.

Sambrook, J.; Fritsch, E. and Maniatis, T. (1989): Molecular cloning: A laboratory manual, second edition. Cold Spring Harbor Laboratory Press.

Schalm, O.W.; Lasmanis, J. and Jain, N.C. (1976): Conversion of chronic staphylococcal mastitis to acute gangrenous mastitis after neutropenia in blood and bone marrow produced by an equine antibovine leukocyte serum. Am. J. Vet. Res., 37, 8, 885-890.

Seddek, S.R.; Abd El-Kader, H.A. and Abd El-Hafeez, M.M. (1999): Bacteriological studies of subclinical mastitis in Friesian cattle in Assiut Governorate. Assiut Vet. Med. J., 42, 83, 7788.

Seegers, H.; Fourichon, C. and Beaudeau, F. (2003): Production effects related to mastitis and mastitis economics in dairy cattle herds. Veterinary Research.; 34: 475-491.

Sharma, Neelesh, Maiti, S.K. and Koley, K.M. (2004): Studies on the incidence of sub clinical mastitis in buffaloes of Rajnandgaon district of Chhattisgarh state. Vet. Practitioner. 5(2): 123124.

Sharma, Neelesh, Maiti, S.K. and Sharma, K.K. (2007): Prevalence, etiology and antibiogram of microorganisms associated with sub clinical mastitis in buffaloes in Durg, Chhattisgrh State (India). International J. Dairy Sci., 2(2): 145151.

Sharma, A. and Sindhu, N. (2007): Occurrence of clinical and subclinical mastitis in buffaloes in the State of Haryana (India). Ital. J. Anim. Sci6 (2): 965 -967.

Soomro, AH.; Arain, MA.; Khaskheli, M. and Bhutto, $B$. (2002): Isolation of $\mathrm{E}$ coli from raw milk and milk products in relation to public health sold under market conditions at Tandojam, Pakistan. Pak. J. Nutri. 1(3): 151-152.

Su, C.; Kanevsky, I.; Jayarao, B.M. and Sordillo, L.M. (2000): Phylogenetic relationships of Staphylococcus aureus from bovine mastitis based on coagulase gene polymorphism. Vet. Microbiol., 71: 53-58.

Toply and Wilson (1998): Microbiology and microbial infections. Ninth Edition. Leslie Collier Aibert Balow. Max Sussman. Copublished in the USA by Oxford Univ. Press Inc.

Yasser Saleem Mustafa; Farhat Nazir Awan and Tooba Zaman (2013): Prevelence and antebacterial suscebtibility in mastitis in buffaloes and cows in district Lahore-Pakistan Buffalo Bulletin (December) Vol.32 No.4. 307-31.

Yu-Ping, S.; Dong-Shun, Z.; Hong-kun, Z.; RenZhong, W.; Wen-Quiang, L. and Jin-Dong, $H$. (2007): A nested PCR-based method for detection of Streptococcus agalactia 16sr RNA in milk and its application. Chinese Journal of Agricultural Biotechnology. Vol (3): 115-118.

Zadoks R. and Schukken Y. (2006): Use of molecular epidemiology in veterinary practice. Veterinary Clinics of North America: Food Animal Practice. 22: 229-261. 


\title{
انتثار واسباب و المضادات الحيويه لالتهاب الضرع فى الجاموس فى محافظه سوهاج<smiles>[Mg][Mg][Mg][Mg]</smiles>

E-mail: nehalmakram63@gmail.com Assiut University web-site: www.aun.edu.eg

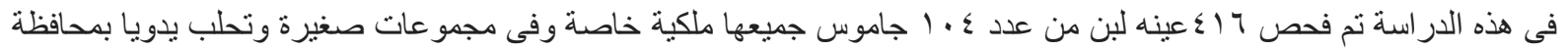

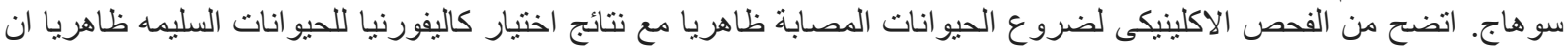

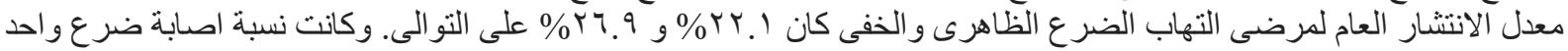

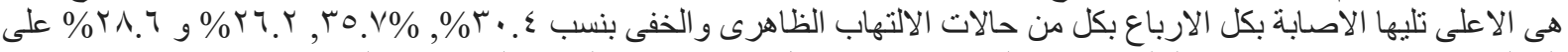

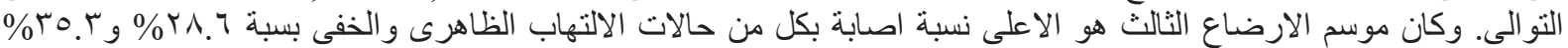

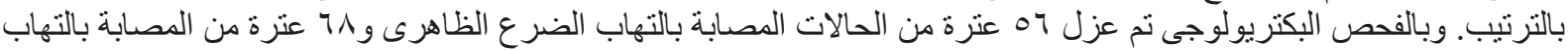

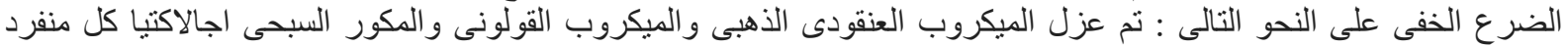

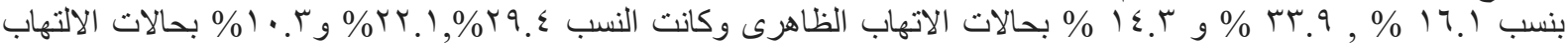

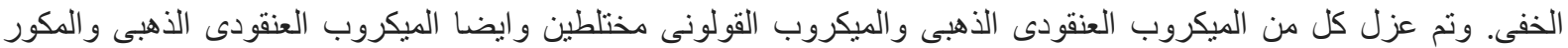

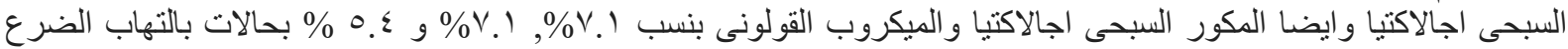

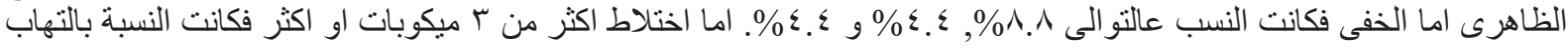

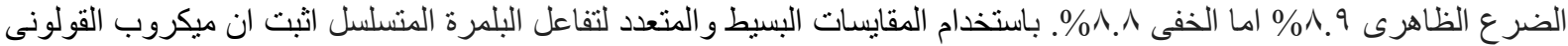

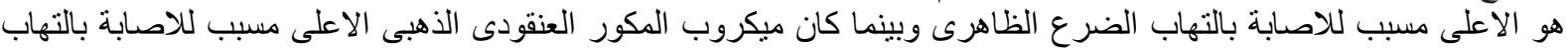

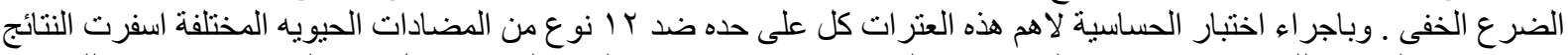
عن حساسيه العترات للجينتاميسن , سييرو فلوكساسين , لينكوميسين و نوفو بيسين يليها كلور رمفينيكول , سيفالوسين و امكسيسيسيللين.
\end{abstract}

